\title{
Growth, health and biochemical composition of the sea cucumber Cucumaria frondosa after multi-year holding in effluent waters of land-based salmon culture
}

\author{
Jiamin Sun ${ }^{1, *}$, Jean-François Hamel ${ }^{2}$, Bruno L. Gianasi ${ }^{1}$, Mike Graham ${ }^{3}$, \\ Annie Mercier ${ }^{1}$ \\ ${ }^{1}$ Department of Ocean Sciences, Memorial University, St John's, NL, A1C 5S7, Canada \\ ${ }^{2}$ Society for the Exploration and Valuing of the Environment (SEVE), St. Philips, NL, A1M 2B7, Canada \\ ${ }^{3}$ Burin Campus, College of the North Atlantic, Burin, NL, A0E 1G0, Canada
}

\begin{abstract}
Methods have been proposed to mitigate the environmental footprint of aquaculture, including co-culture of species occupying different trophic levels. In this study, sea cucumbers Cucumaria frondosa, either from production tanks fed with effluent water from land-based salmon culture over $4 \mathrm{yr}$ or collected from the field, were compared using stable isotope, lipid and fatty acid (FA) signatures as indicators of waste assimilation, health and biochemical composition. Enrichment of $\delta^{13} \mathrm{C}$ in muscle bands and intestine and of $\delta^{15} \mathrm{~N}$ in muscle bands, gonad and intestine was detected in captive individuals relative to wild individuals, suggesting the uptake and assimilation of waste from salmon culture. The higher levels of FA biomarkers typical of salmon feed $(18: 1 \omega 9,18: 2 \omega 6$ and 20:1 $\omega 9)$ and lower $\omega 3 / \omega 6$ ratio in the captive sea cucumbers were also in line with assimilation of the waste. However, male and female sea cucumbers from the co-culture became smaller with time, their organ indices were lower than those of wild individuals (e.g. poorly developed gonad), and their biochemical composition differed: triacylglycerol content was greater in wild individuals and phospholipid content was greater in captive individuals. Also, FA profiles of all tissues differed between the 2 groups, whereas total lipid in muscle bands and gonad remained similar. Overall, results support that co-culture with suspension-feeding sea cucumbers may help mitigate the salmon industry footprint. In turn, the biochemical composition of the sea cucumbers changed, and their reduced size and body indices suggest that this food source does not provide suitable nutrients to sustain growth and reproduction.
\end{abstract}

KEY WORDS: Co-culture · Holothuroid · Suspension-feeder - Salmon · IMTA · Stable isotope • Fatty acid

\section{INTRODUCTION}

Atlantic salmon Salmo salar is one of the most intensively farmed marine fish, owing to its amenability to high stocking densities and rapid growth, and to well established international markets (Jobling et al. 2010). Canada is the world's fourth largest producer of farmed salmon, including Atlantic, Chinook and coho salmon (DFO 2017). Although salmon farm-

\footnotetext{
*Corresponding author: jiamins@mun.ca
}

ing brings unquestionable economic benefits, concern about its environmental costs is growing. Whether the expansion of intensive marine-finfish aquaculture can be sustained is being questioned in light of the potential effect of inorganic and organic wastes produced by fish farms (Navarrete-Mier et al. 2010, Wang et al. 2012). Atlantic salmon culture releases extra nitrogen $(\mathrm{N})$ and phosphorus (P) and produces organic wastes in the form of unconsumed

(C) The authors 2020. Open Access under Creative Commons by Attribution Licence. Use, distribution and reproduction are unrestricted. Authors and original publication must be credited. 
feed and feces (Pillay 2008). One $t$ of salmon production results in the release of $60 \mathrm{~kg}$ of $\mathrm{N}$ and $13 \mathrm{~kg}$ of $\mathrm{P}$ waste loads (Chatvijitkul et al. 2017). Consequently, salmon farming using sea cages may lead to eutrophication of the water column, while solid waste accumulates on the ocean floor, impacting the oxygen demand at the substrate/benthos and leading to a decline of oxygen-sensitive species in favor of more resistant opportunistic species (Pillay 2008, Mayor \& Solan 2011).

To make fish farming more sustainable in the long term, emphasis has been placed on exploring landbased models (Shpigel et al. 1993) and/or using integrated multi-trophic aquaculture (IMTA), which has the potential to reduce waste loading and environmental impacts and to increase the efficiency and productivity of intensive monoculture systems (Neori et al. 2004). In brief, IMTA makes use of by-products, including wastes, from one aquatic species to provide nutrients to another (Troell et al. 2009, Chopin et al. 2012). IMTA involves the culture of aquatic animals and the use of their waste products (excess feed and feces) as a food source for other commercially viable extractive species to favor environmental remediation, economic stability and social acceptability (Ridler et al. 2007, Troell et al. 2009). Many species have successfully been integrated into IMTA systems to extract inorganic and organic waste, such as seaweed (Kang et al. 2008, Abreu et al. 2011), mussels (Reid et al. 2010, MacDonald et al. 2011, Irisarri et al. 2015) and sea urchins (Orr et al. 2014, Sterling et al. 2016).

Sea cucumbers are high-value products from marine aquaculture and fisheries; they have also been identified as prospective extractive species for IMTA due to their ability to feed on the particulate waste generated by other animals (Zamora et al. 2018). Many studies have shown them to be good candidates for co-culture with finfish (Ahlgren 1998, Hannah et al. 2013, Yokoyama 2013), bivalves (Zhou et al. 2006, Slater \& Carton 2007, Paltzat et al. 2008, Yokoyama 2015), gastropods (Kang et al. 2003, Maxwell et al. 2009) and jellyfish (Ren et al. 2014). In one case, Kang et al. (2008) co-cultured the depositfeeding sea cucumber Apostichopus japonicus and the abalone Haliotis discus in circulating culture tanks to clean up the hatchery effluent of abalones during the heating-aided overwintering period. They showed that ammonia and nitrite contents in seawater decreased, and that the survival and growth rates increased in co-cultured abalone compared to abalone cultured alone in the same experimental setup, but they did not measure the outcome for sea cucumbers. Hannah et al. (2013) suggested that another deposit-feeding species (Parastichopus californicus) suspended directly below net pens of sablefish Anoplopoma fimbria grew faster and reduced the total organic carbon (C) and total $\mathrm{N}$ contents of the fish feces by an average of 60 and $62 \%$, respectively. The potential use of suspension-feeding sea cucumbers remains comparatively understudied and is only starting to be explored.

Cucumaria frondosa is the most common sea cucumber in the North Atlantic and one of the most abundant worldwide, occurring off New England (USA), in eastern and Arctic Canada, Greenland and Scandinavia, as well as in the Faroe Islands and Russia (Jordan 1972, Hamel \& Mercier 2008). Like many other commercially important sea cucumber species, C. frondosa has been fished extensively in its distribution range to meet the increasing demand from Asia (Hamel \& Mercier 2008). However, C. frondosa differs from most previously cultured holothuroid species. It is a cold-water species and a passive suspension-feeder that captures a wide range of particulate food $(4-1500 \mu \mathrm{m})$ by extending its tentacles in the water column (Hamel \& Mercier 1998, Gianasi et al. 2017). Interest has recently increased in using $C$. frondosa as a biofilter within IMTA systems to help reduce particulate organic loading (Nelson et al. 2012). C. frondosa can ingest excess salmon feed and feces efficiently, both in the laboratory and in the natural environment, making it a candidate biofilter within an IMTA setting (Nelson et al. 2012). What remains untested is whether individuals in this IMTA system can use energy from the ingested wastes to grow and whether their overall health and biochemical profile differ from those of wild individuals.

Organic matter can be incorporated into the tissue of an animal via its diet (Peterson \& Fry 1987), and its assimilation can be measured by a shift in the $\mathrm{C}$ and N stable isotope signatures (Post 2002). Moreover, fatty acid (FA) biomarkers can be used to trace specific lipid sources and make inferences about the diet of aquatic animals. In recent years, greater levels of plant oils have been incorporated into salmon feed to reduce costs and minimize dependence on fish oil sources; such terrestrial lipid sources naturally con-

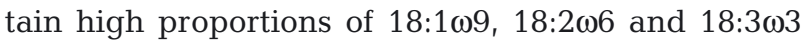
(Skog et al. 2003, Narváez et al. 2008), which can be used as tracers of fish feed.

The present study was designed to compare several key metrics between wild individuals of $C$. frondosa and individuals held for $4 \mathrm{yr}$ in the effluent of an Atlantic salmon culture (i.e. IMTA sys- 
tem). The stable $\mathrm{C}$ and $\mathrm{N}$ isotope signatures and specific FAs in tissues were studied to confirm whether the co-cultured sea cucumbers assimilated the waste products coming from the salmon. Also, their general health condition and biochemical composition were measured to determine if sea cucumbers could be sustained on the effluent waste from salmon culture. In particular, we assessed whether co-cultured sea cucumbers could not only survive but also grow and eventually reproduce in captivity.

\section{MATERIALS AND METHODS}

\subsection{Captive holding conditions (IMTA)}

The experiment was performed in a land-based aquaculture facility (Wave Energy Research Centre of College of the North Atlantic) in Lord's Cove, Newfoundland (Canada), which was designed to demonstrate the viability of cascaded IMTA in an open flow-through tank system. In this system, the effluent from the finfish (the only organisms receiving external feed input) was directed to sea cucumber production tanks. From there, water flowed to scallop production tanks and finally algae cultures. Seawater (fluctuating between $-0.8^{\circ} \mathrm{C}$ in winter and a maximum of $12.0^{\circ} \mathrm{C}$ in summer) was pumped into the facility from $120 \mathrm{~m}$ offshore at $10 \mathrm{~m}$ depth. It was sand filtered to $200 \mu \mathrm{m}$ before passing through a degassing column on the way to a 70001 header tank. The filtered seawater was delivered directly to 3 cylindrical tanks (8000 l capacity, $2.9 \mathrm{~m}$ diameter $\times$ $1.3 \mathrm{~m}$ depth). Around 200 juvenile (70-80 g) Atlantic salmon were cultured in the 3 tanks ( 70 ind. $\operatorname{tank}^{-1}$ ) with flow-through water $\left(\sim 3000 \mathrm{l} \mathrm{h}^{-1}\right)$. They were fed the equivalent of $5-90 \mathrm{~g}$ of feed $(3.0-7.0 \mathrm{~mm}$, EWOS ${ }^{\circledR}$ ) per day per fish, depending on the size of fish. Two-thirds of the effluent water from the salmon tanks was thoroughly mixed in a common head tank before being directed through a valve system at a rate of 25-30 $1 \mathrm{~min}^{-1}$, to two $2000 \mathrm{l}$ rectangular tanks (3.2 m length $\times 1.6 \mathrm{~m}$ width $\times 0.4 \mathrm{~m}$ depth), each containing $\sim 350$ adults of Cucumaria frondosa $(9-17 \mathrm{~cm}$ in contracted length, $\sim 70$ ind. $\mathrm{m}^{-2}$ ). No shelter was provided for sea cucumbers, and light was provided through several windows and multiple fluorescent lights suspended above the tanks (32 W, 5000 Kelvin white T8, $250 \mathrm{~lx}$ ) following natural photoperiod. All sea cucumbers had been collected by licensed harvesters at depths between 20 and $30 \mathrm{~m}$ in October 2013.

\subsection{Sample collection for body indices and chemical analysis}

To assess the state of sea cucumbers in the IMTA system, 20 individuals from each tank (40 individuals in total) were sampled haphazardly after 20 mo (June 2015) and after 32 mo (June 2016) and their wet weights were measured. At the end of the study in August 2017, after 45 mo under IMTA conditions, 12 sea cucumbers were collected from each of 2 holding tanks ( $\mathrm{n}=24$ total). For comparison purposes, 24 adults were collected from the wild at approximately the same date ( $10 \mathrm{~d}$ earlier). These wild sea cucumbers were of similar size, came from the same area (Grand Bank, NAFO division 3Ps) and were caught using the same fishing gear as those placed in the IMTA $4 \mathrm{yr}$ prior. Individuals from the IMTA system and from the wild were transported to the laboratory in coolers with iced seawater (Gianasi et al. 2016) and separately held in 2 tanks (500 l) with filtered seawater $(200 \mu \mathrm{m})$ for $4 \mathrm{~d}$ to allow all feces to be evacuated.

The total wet weight of each individual ( $\mathrm{n}=48$ ) was obtained and the sex of each individual was determined with a gonad smear when determination from the genital papilla described by Montgomery et al. (2018) could not be made. All individuals were dissected and their different organs/ tissues (body wall, longitudinal and circular muscle bands, intestine, respiratory tree) were separately weighed and stored at $-20^{\circ} \mathrm{C}$ for further analysis. The wet weight of the body wall (without the aquapharyngeal bulb and muscle bands) was chosen as a denominator to establish the different organ indices (Hamel \& Mercier 1996a). All indices were calculated as the ratio of wet organ weight to wet body wall weight.

In addition, the fish feed and the particulate wastes, representing the main food sources for the sea cucumbers held in the IMTA system, were collected from 4 locations on the bottom of the effluent mixed tank (described above) by siphoning and passing through a $100 \mu \mathrm{m}$ mesh. The filtrates were stored at $-20^{\circ} \mathrm{C}$ until further analysis.

\subsection{Sample analysis}

The organs (longitudinal and circular muscle bands, intestine, gonad) of 4 males and 4 females from the IMTA system and 4 males and 4 females from the wild, together with the waste samples from effluent water, were submitted for the following 
analyses to assess whether captive sea cucumbers assimilated the waste from salmon tanks and to determine their respective biochemical composition.

\subsubsection{Stable isotope and elemental analyses}

Samples $(0.5-1.0 \mathrm{~g})$ were oven-dried at $70^{\circ} \mathrm{C}$ for $24 \mathrm{~h}$ and then ground into a fine powder using mortar and pestle. To get rid of carbonates that might affect the stable $\mathrm{C}$ isotope ratio data, hydrochloric acid $(\mathrm{HCl}, 1 \mathrm{M})$ was added dropwise to waste samples until bubbles stopped forming. Samples were then rinsed 3 times with distilled water and oven dried again. Subsamples of $1 \mathrm{mg}$ were packed into tin cups and simultaneously analyzed for stable $\mathrm{C}$ and $\mathrm{N}$ isotope ratios, and for elemental $\mathrm{C}$ and $\mathrm{N}$, at the Earth Resources Research and Analysis (TERRA) of the Core Research Equipment and Instrument Training Network (CREAIT) of Memorial University, using a Delta V Plus (Carlo Erba) continuous-flow isotoperatio mass spectrometer. Isotope ratios are expressed in the conventional notation (i.e. $\delta^{13} \mathrm{C}$ and $\delta^{15} \mathrm{~N}, \%$ ), following the equation:

$$
\delta^{15} \mathrm{~N} \text { or } \delta^{13} \mathrm{C}=\left[\left(\mathrm{R}_{\text {sample }} / \mathrm{R}_{\text {standard }}\right)-1\right] \times 1000
$$

where $\mathrm{R}_{\text {sample }}$ is the ratio of ${ }^{13} \mathrm{C} /{ }^{12} \mathrm{C}$ or ${ }^{15} \mathrm{~N} /{ }^{14} \mathrm{~N}$. Average SD of selected replicates was $\pm 0.1 \%$ for $\delta^{15} \mathrm{~N}$ and $\pm 0.1 \%$ for $\delta^{13} \mathrm{C}$. Total elemental $\mathrm{C}$ and $\mathrm{N}$ were measured as \% of dry mass, and average SD was \pm 3.2 for $\% \mathrm{C}$ and \pm 0.1 for $\% \mathrm{~N}$. L-valine, USGS-24 graphite, IAEA-CH-6 sucrose, LSVEC, MUN-CO-1 and MUN$\mathrm{CO}-2$ were used as standards for stable $\mathrm{C}$ isotopes. IAEA-N-1, USGS-25, USGS-26 and L-valine were used to assess accuracy and precision of stable $\mathrm{N}$ isotope data. B2155 protein was used as a standard for $\delta^{13} \mathrm{C}$ and $\delta^{15} \mathrm{~N}$.

\subsubsection{Lipid content and lipid class analyses}

Samples of muscle bands, gonad and intestine $(0.5-1.0 \mathrm{~g})$ were collected from each still-frozen individual to limit lipid oxidation and hydrolysis. Also, 4 samples of 3.5-4.5 g of waste were collected from the effluent mixing tank. Each sample was immersed in chloroform $(8 \mathrm{ml})$, topped up with $\mathrm{N}$ gas $\left(\mathrm{N}_{2}\right)$, sealed with Teflon tape and stored in a freezer at $-20^{\circ} \mathrm{C}$ until extraction.

Lipids were extracted and analyzed following Parrish (1999). Briefly, samples were homogenized in a chloroform:methanol:water (2:1:1) mixture, sonicated for $5 \mathrm{~min}$ and centrifuged for $2 \mathrm{~min}$. The bottom, organic layer was removed using a double pipetting technique involving placing 2 pipettes inside one another. Chloroform was then added to the sample, and the procedure was repeated 3 times. The top layer (lipid extracts) was pooled into a lipid-clean vial, and the total amount was blown down to volume under a gentle stream of N. Vials were sealed and stored at $-20^{\circ} \mathrm{C}$ until lipid and FA analysis.

Lipid classes were determined by thin-layer chromatography with flame ionization detection (FID) using an Iatroscan MK-6 and a 3-stage development system to separate lipid classes. The first separation consisted of $25 \mathrm{~min}$ and $20 \mathrm{~min}$ developments in a mixture of hexane:diethyl ether:formic acid (98.95:1:0.05). The second development used a mixture of hexane:diethyl ether:formic acid (79.9:20:0.1) for $40 \mathrm{~min}$. The last separation consisted of a 15 min development of $100 \%$ acetone followed by two $10 \mathrm{~min}$ developments in chloroform:methanol:chloroform-extracted-water (5:4:1). Lipid classes were identified and quantified through comparison with a prepared standard. Data were processed using the PeakSimple Chromatography software (V4.51, SRI Instruments).

\subsubsection{FA analysis}

FAs were determined from the same samples previously used for lipid class analysis. The FA derivatization procedure is based on Parrish (1999). Briefly, an aliquot of the lipid extracts (muscle bands, $100 \mu l_{i}$ intestine and gonad, $30 \mu \mathrm{l}$; waste, $10 \mu \mathrm{l}$ ), calculated in relation to the total amount of lipids within each sample, was transferred into a lipid clean vial and dried under $\mathrm{N}_{2}$. After the addition of $1.5 \mathrm{ml}$ of dichloromethane and $3 \mathrm{ml}$ of Hilditch reagent (i.e. $\mathrm{H}_{2} \mathrm{SO}_{4}$ dissolved in methanol), the vials were sonicated, sealed with Teflon tape and heated for $1 \mathrm{~h}$ at $100^{\circ} \mathrm{C}$. After cooling, $0.5 \mathrm{ml}$ of saturated sodium bicarbonate and $1.5 \mathrm{ml}$ of hexane were added to each vial, thus creating 2 layers. The upper, organic layer was removed and transferred into a new lipid clean vial. Finally, the solution was blown dry under $\mathrm{N}_{2}$, and $0.5 \mathrm{ml}$ of hexane was added to each vial. Vials were then sealed and kept at $-20^{\circ} \mathrm{C}$ until analysis. The samples were analyzed as FA methyl esters (FAMEs) on an HP 6890 Gas Chromatograph FID equipped with a 7683 autosampler. Chromatograms were compared to a prepared standard and analyzed using the software Varian Galaxie Chromatography Data System. Shorthand FA notations of the form $A: B \omega X$ were used, where A represents the number of carbon atoms, $\mathrm{B}$ the number of double bonds, and $\mathrm{X}$ is the 
position of the first double bond closest to the terminal methyl group $\left(\mathrm{CH}_{3}\right)$.

\subsection{Statistical analysis}

All data were tested for normality and equal variance using Kolmogorov-Smirnov and Levene's tests $(\alpha=0.05)$, respectively. Wet weights of sea cucumbers from the field (wild individuals) and from the IMTA system (captive individuals) were compared at different time points using 1-way ANOVA followed by post hoc multiple comparisons with Tukey's test. Differences in health condition between wild and captive individuals were assessed using $t$-test for each organ index (muscle bands, intestine, gonad and respiratory tree). Stable isotopes $\left(\delta^{15} \mathrm{~N}\right.$ and $\left.\delta^{13} \mathrm{C}\right)$ and elemental $\mathrm{N}(\% \mathrm{~N})$ and $\mathrm{C}$ $(\% \mathrm{C})$, and total lipid content as well as some specific FAs were also compared between the 2 groups using $t$-tests. Permutational multivariate ANOVA (PERMANOVA) was performed to explore the FA composition variability among captive and wild individuals, and waste. Data in the text are expressed as mean $\pm \mathrm{SD}$. Statistical analyses were conducted with Sigmaplot ${ }^{\circledR} 14.0$ (Systat Software) and Primer ${ }^{\circledR} 5$ (Primer-E).

\section{RESULTS}

\subsection{Morphological metrics and organ indices}

Overall, the survival rate of sea cucumbers under IMTA over nearly 4 yr was around $90 \%$, and the wet weight of captive individuals varied significantly over time $\left(F_{3,124}=18.56, \mathrm{p}<0.001\right)$. The wet weight of captive individuals decreased from $253 \pm 52 \mathrm{~g}$ in June 2015 to $122 \pm 60 \mathrm{~g}$ in August 2017 (Fig. 1). The freshly collected wild sea cucumbers $(229 \pm 48 \mathrm{~g})$ were significantly larger than the captive individuals at the end of this study (Tukey's test, $\mathrm{p}<0.001$ ) and showed higher organ indices (Figs. 1 \& 2). All organ indices of wild individuals were significantly greater than those of captive individuals, in both males (muscle bands, $t=3.78, \mathrm{df}=16, \mathrm{p}=0.002$; intestine, $t=$ $3.30, \mathrm{df}=16, \mathrm{p}=0.005 ;$ gonad, $t=3.48, \mathrm{df}=16, \mathrm{p}=$ 0.003 ; respiratory tree, $t=2.38, \mathrm{df}=16, \mathrm{p}=0.030$ ) and females (muscle bands, $t=5.76, \mathrm{df}=20, \mathrm{p}<0.001$; intestine, $t=2.16, \mathrm{df}=20, \mathrm{p}=0.043$; gonad, $t=3.53$, $\mathrm{df}=20, \mathrm{p}=0.002$; respiratory tree, $t=2.28, \mathrm{df}=20$, $\mathrm{p}=0.017$; Fig. 2). All wild sea cucumbers had welldeveloped gonad tubules, with the presence of red-

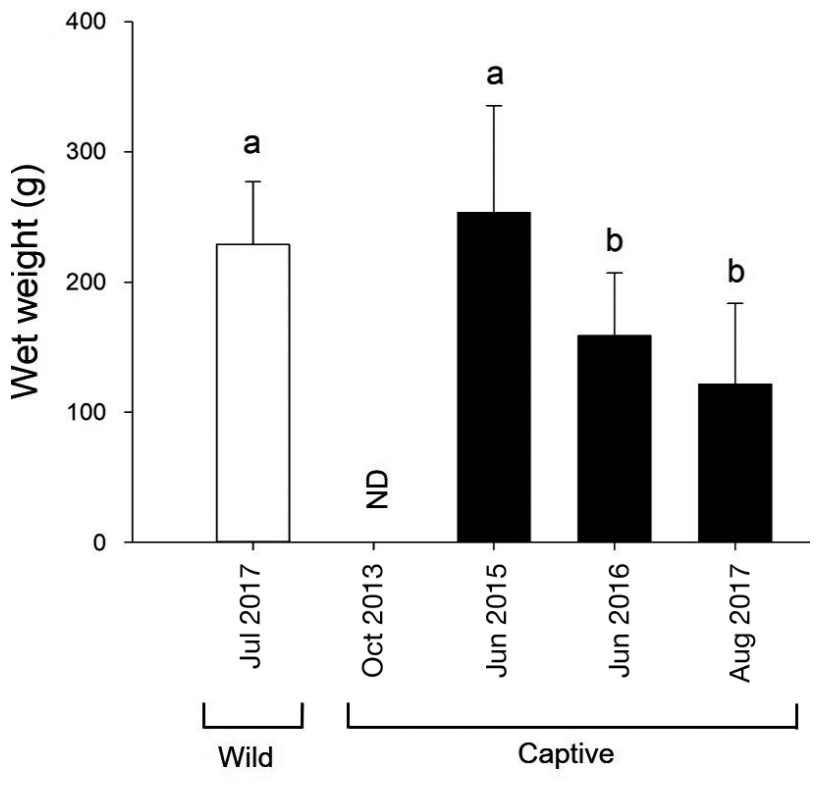

Fig. 1. Wet weight of wild individuals of Cucumaria frondosa (collected in 2017) and wet weight of captive individuals over time (2013-2017). Data are shown as means \pm SD $(n=24$ for wild and captive individuals in 2017; $\mathrm{n}=40$ for 2015 and 2016). Means with different letters are significantly different (Tukey's test, $\mathrm{p}<0.05)$. ND: not determined

dish vitellogenic oocytes and small yellowish oocytes (see Fig. S1A in the Supplement at www.int-res.com/ articles/suppl/q012p139_supp.pdf), whereas only $67 \%$ of captive sea cucumbers had a gonad, and when present, it was consistently smaller than in wild counterparts (Fig. S1B). Among all organ indices, the gonad index displayed the greatest difference; with $22.0 \pm 11.7 \%$ in wild males and $27.0 \pm 15.1 \%$ in wild females, which was roughly 3 times the gonad index measured in captive males $(7.2 \pm 3.0 \%)$ and females (7.5 $\pm 4.4 \%$; Fig. 2$)$.

\subsection{Stable isotope and elemental analyses}

Stable N isotope ratios $\left(\delta^{15} \mathrm{~N}\right)$ of all organs of captive individuals were significantly greater than those of wild individuals, for both sexes (Table S1). Specifically, a marked difference in $\delta^{15} \mathrm{~N}$ of intestine occurred between captive and wild individuals (male, $t=-12.51, \mathrm{df}=6, \mathrm{p}<0.001$; female, $t=-11.17$, $\mathrm{df}=6, \mathrm{p}<0.001)$. Stable $\mathrm{C}$ isotope ratios $\left(\delta^{13} \mathrm{C}\right)$ of muscle bands were significantly greater in captive than in wild individuals (male, $t=-3.83, \mathrm{df}=6, \mathrm{p}=$ 0.009 ; female, $t=-3.10, \mathrm{df}=6, \mathrm{p}=0.020$ ). The same was true of the $\delta^{13} \mathrm{C}$ of intestine in both males $(t=$ $-6.19, \mathrm{df}=6, \mathrm{p}<0.001)$ and females $(t=-3.52, \mathrm{df}=6$, 

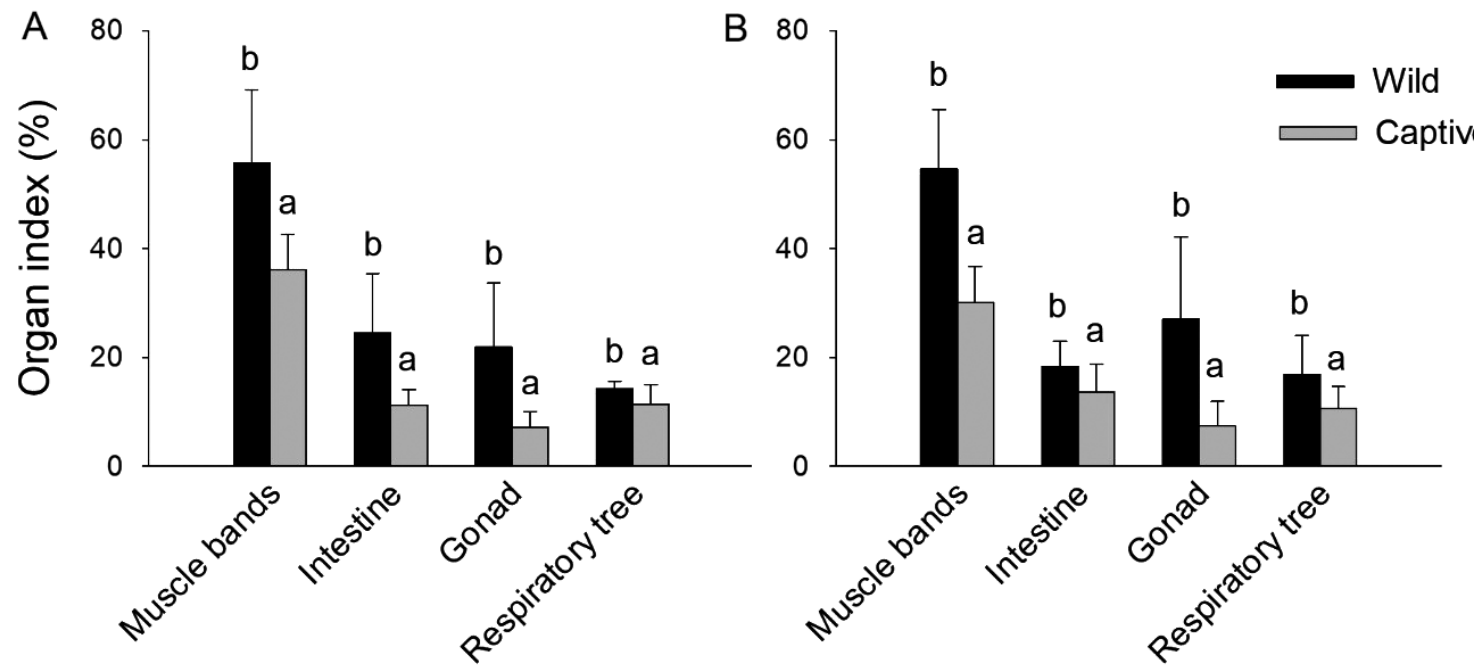

Fig. 2. Organ indices of (A) male and (B) female individuals of wild and captive (45 mo under IMTA conditions) Cucumaria frondosa. Data are shown as means $\pm \mathrm{SD}\left(\mathrm{n}=10\right.$ for wild and $\mathrm{n}=8$ for captive in $\mathrm{A}_{i} \mathrm{n}=14$ for wild and $\mathrm{n}=8$ for captive in $\mathrm{B}$ ). Means with different letters are significantly different $(t$-test, $\mathrm{p}<0.05)$

$\mathrm{p}=0.013)$. However, no significant differences in $\delta^{13} \mathrm{C}$ of the gonad was found between the 2 groups for males $(t=0.06, \mathrm{df}=6, \mathrm{p}=0.953)$ or females $(t=$ $-0.19, \mathrm{df}=6, \mathrm{p}=0.857$ ). Overall, sea cucumbers held in the IMTA system displayed enrichment in $\delta^{13} \mathrm{C}$ and $\delta^{15} \mathrm{~N}$ relative to those collected from the wild (Fig. 3). In addition, $\delta^{13} \mathrm{C}$ and $\delta^{15} \mathrm{~N}$ values obtained for the samples of salmon waste were $-22.4 \pm 0.3 \%$ and $11.8 \pm 0.2 \%$, respectively.

The concentration of elemental $\mathrm{N}$ was greater in captive than in wild individuals for muscle bands and intestine, but not for the gonad. Specifically, the concentration of elemental $\mathrm{N}$ in percent dry mass was significantly greater in the muscle bands $(t=-3.35$, $\mathrm{df}=6, \mathrm{p}=0.015)$ and intestine $(t=-3.49, \mathrm{df}=6, \mathrm{p}=$ 0.013 ) of captive than wild males. The same was true in females for both muscle bands $(t=-3.86, \mathrm{df}=6$, $\mathrm{p}=0.008)$ and intestine $(t=-3.85, \mathrm{df}=6, \mathrm{p}=0.008)$. However, the percent dry mass of $\mathrm{N}$ in the gonad was significantly greater in wild than in captive individuals for males $(t=2.13, \mathrm{df}=6, \mathrm{p}=0.048)$ and females $(t=2.66, \mathrm{df}=6, \mathrm{p}=0.038)$. The concentration of elemental $\mathrm{C}$ in percent dry mass was significantly greater in the muscle bands $(t=-3.12, \mathrm{df}=6, \mathrm{p}=$ $0.021)$ and gonad $(t=-6.86, \mathrm{df}=6, \mathrm{p}<0.001)$ of captive than wild males. The same was true in females for both muscle bands $(t=-4.18, \mathrm{df}=6, \mathrm{p}=0.006)$ and gonad $(t=-4.92, \mathrm{df}=6, \mathrm{p}=0.003)$. The percent dry mass of elemental $\mathrm{C}$ in the intestine was significantly greater in captive than in wild females $(t=-2.57, \mathrm{df}=$ $6, p=0.042$ ) but no significant difference occurred in males $(t=-0.81, \mathrm{df}=6, \mathrm{p}=0.450)$.

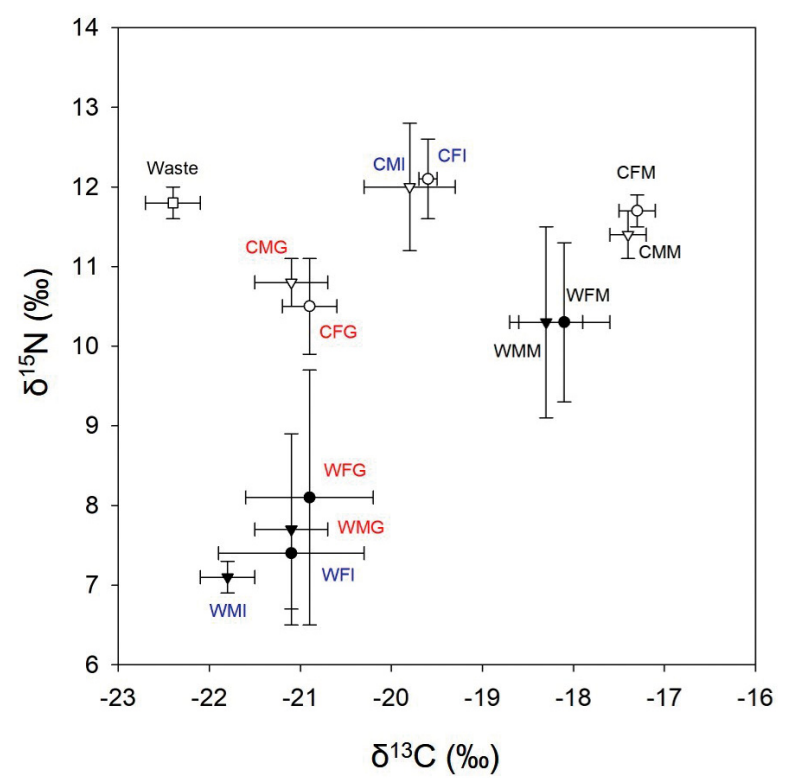

Fig. 3. Biplot of $\delta^{13} \mathrm{C}$ and $\delta^{15} \mathrm{~N}$ in the muscle bands, intestine and gonad of wild and captive (45 mo under IMTA conditions) Cucumaria frondosa (males and females) and in the waste from salmon tanks (food for captive individuals). All data are shown as means \pm SD $(n=4)$. WMM (WFM): wild male (female) muscle bands; WMI (WFI): wild male (female) intestine; WMG (WFG): wild male (female) gonad; CMM (CFM): captive male (female) muscle bands; CMI (CFI): captive male (female) intestine; CMG (CFG): captive male (female) gonad. To clearly identify different tissues, the abbreviations for muscle bands, intestine and gonad are shown in black, blue and red, respectively. The triangles and circles represent male and female individuals, respectively, and the closed and open symbols represent wild and captive individuals, respectively. The open square corresponds to salmon culture waste material 
A

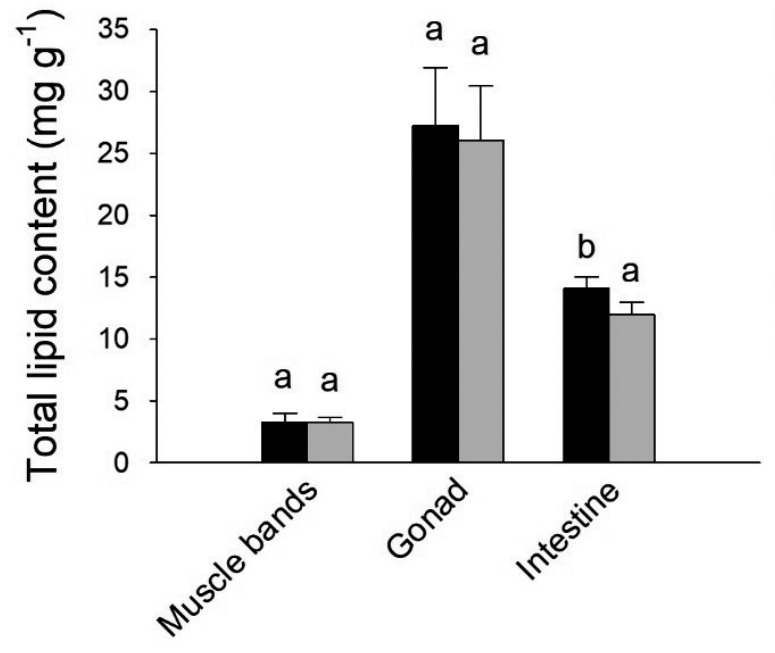

B

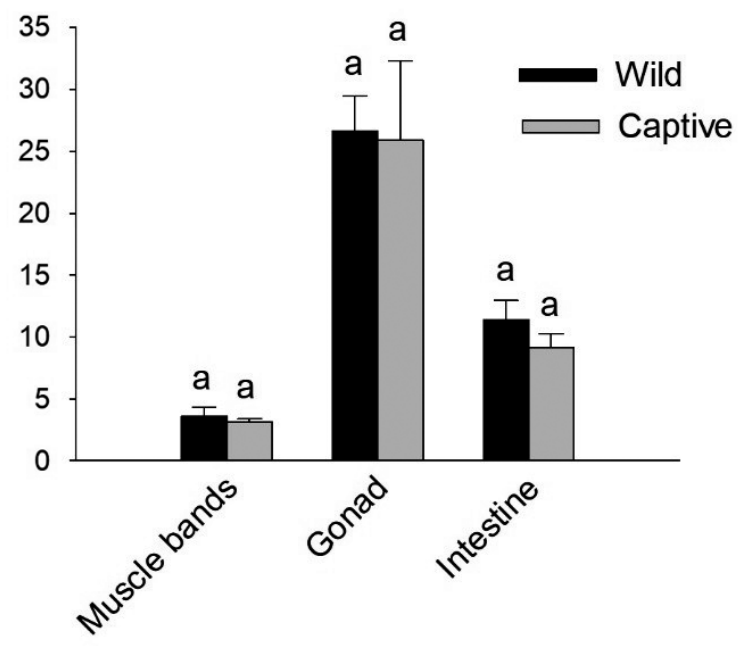

Fig. 4. Total lipids in muscle bands, gonad and intestine of (A) male and (B) female individuals of wild and captive (45 mo under IMTA conditions) Cucumaria frondosa. Data are shown as means $\pm \mathrm{SD}(\mathrm{n}=4)$. Comparisons were made between wild and captive individuals $(t$-test), and means with different letters are significantly different $(\mathrm{p}<0.05)$

\subsection{Lipid classes and total lipids}

The following lipid classes were found in all tissues of wild and captive sea cucumbers: acylated glyceryl ethers, triacylglycerols (TAGs), sterols and phospholipids (PLs). However, hydrocarbons were only found in gonad tissue, and acetone mobile polar lipids (AMPLs) occurred in the gonad and intestine but not in muscle bands. For both groups of sea cucumbers, total lipid content was generally higher in the gonad (males: captive, $26.0 \mathrm{mg} \mathrm{g}^{-1}$; wild, $27.2 \mathrm{mg} \mathrm{g}^{-1}$, females: captive, $25.9 \mathrm{mg} \mathrm{g}^{-1}$; wild, $26.6 \mathrm{mg} \mathrm{g}^{-1}$ ) than in the intestine (males: captive, $12.0 \mathrm{mg} \mathrm{g}^{-1}$; wild, $14.1 \mathrm{mg} \mathrm{g}^{-1}$, females: captive, $9.2 \mathrm{mg} \mathrm{g}^{-1}$; wild, 11.4 $\mathrm{mg} \mathrm{g}^{-1}$ ) and muscle bands (males: captive, $3.2 \mathrm{mg} \mathrm{g}^{-1}$; wild, $3.3 \mathrm{mg} \mathrm{g}^{-1}$, females: captive, $3.1 \mathrm{mg} \mathrm{g}^{-1}$; wild, $3.6 \mathrm{mg} \mathrm{g}^{-1}$, Fig. 4).

For all tissues examined in both sexes, total lipid contents were consistent between wild and captive sea cucumbers, except for the intestine of males, where the total lipid levels were significantly greater in wild $\left(14.1 \pm 1.0 \mathrm{mg} \mathrm{g}^{-1}\right)$ than in captive individuals $\left(12.0 \pm 1.0 \mathrm{mg} \mathrm{g}^{-1}, t=2.98, \mathrm{df}=6, \mathrm{p}=\right.$ 0.025; Fig. 4). When comparing each lipid class between wild and captive sea cucumbers, the gonad of the latter displayed low content of AMPLs (males, $0.20 \pm 0.05 \mathrm{mg} \mathrm{g}^{-1}$; females, $0.23 \pm 0.06 \mathrm{mg}$ $\mathrm{g}^{-1}$ ), whereas AMPLs were not detected in the gonad of wild individuals. PL content was greater in captive than wild individuals, and inversely, TAG content was higher in wild individuals for both sexes (Table 1).

\subsection{Fatty acids}

For both groups of sea cucumbers, the most abundant FAs in muscle bands were eicosapentaenoic acid, 20:5 1 3 (EPA; 27.8-36.0\%); docosatetraenoic acid, 22:4 $106(9.0-20.0 \%) ;$ and hexadecatetraenoic

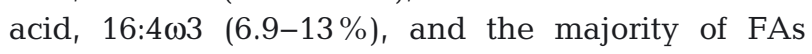
found in the gonad comprised palmitoleic acid, 16:1 $107(20.4-22.5 \%)$ and EPA (12.7-22.5\%). Also, large proportions of EPA (31.3-36.4\%) were found in the intestine of both wild and captive sea cucumbers.

FA composition of all the tissues (muscle bands, gonad and intestine) differed between wild and captive sea cucumbers, in both sexes, and between sea cucumber tissues and waste material (Figs. S2-S4); these differences were significant according to the PERMANOVA (Table S2). When comparing each FA between wild and captive individuals, 16:1 107 content was greater in all tissues of the former for both sexes (Table 2); however, the contents of oleic acid (18:1 $\omega 9)$,

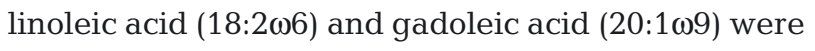
greater in the tissues of captive than wild individuals.

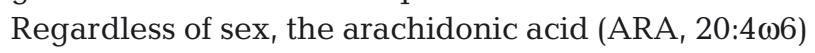
contents of muscle bands and intestine were greater in captive than in wild individuals. The EPA contents in tissues of wild individuals were largely similar to those of captive individuals, i.e. in female intestine $(t=0.56, \mathrm{df}=6, \mathrm{p}=0.598)$ and muscle bands $(t=1.32$, $\mathrm{df}=6, \mathrm{p}=0.237)$ and in male intestine $(t=-0.26, \mathrm{df}=$ $6, \mathrm{p}=0.807)$, but not muscle bands $(t=4.79, \mathrm{df}=6$, $\mathrm{p}=0.003)$. In contrast, the contents in the gonad were nearly double in wild (21.0-22.5\%) compared 


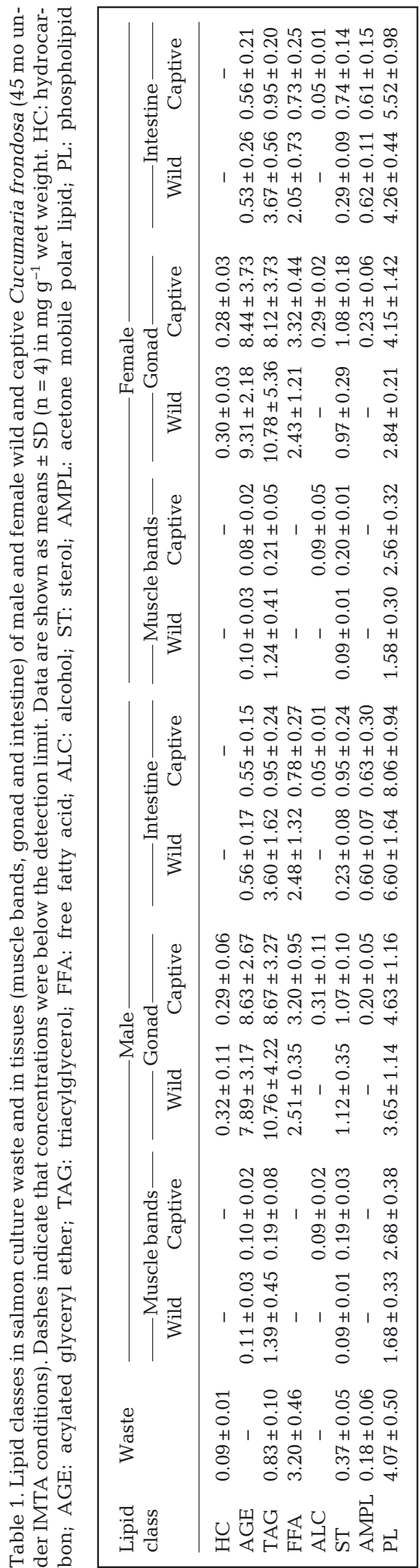

to captive individuals (12.7-13.5\%). Docosahexaenoic acid (DHA, 22:6 63 ) was detected in the gonad of wild individuals but not in the gonad of captive individuals; moreover, DHA content in the intestine of both males and females of captive individuals $(3.9-4.7 \%)$ was roughly 3 times that found in wild counterparts $(1.1-1.3 \%)$.

\section{DISCUSSION}

While Cucumaria frondosa has been identified as a potential candidate for IMTA, limited information currently exists on the suitability of this species or any suspension-feeding sea cucumber in such systems. From a study of $C$. frondosa either held close to a fish farming site or held in the laboratory supplemented with fish feed and feces, Nelson et al. (2012) found that it was capable of capturing and ingesting excess salmon feed and feces, suggesting its potential use as an extractive species. The isotope and FA profiles determined here support that $C$. frondosa not only ingests but can assimilate the organic waste of effluent water from salmon farming. However, the net outcome for its health appears to be negative, with a clear decrease in body size over time, suggesting auto-digestion of tissues, as described previously for that species when exposed to suboptimal food supply (So et al. 2010).

Assimilation of food resources is known to be reflected in the stable isotope signature of animal tissues (Peterson \& Fry 1987), which gets shifted towards that of the food source (Post 2002). Here, individuals held in a land-based IMTA system along with salmon for nearly $4 \mathrm{yr}$ displayed enrichment in $\delta^{13} \mathrm{C}$ and $\delta^{15} \mathrm{~N}$ relative to those collected from the wild. The food available in the IMTA was chiefly composed of salmon waste (residual feed and feces) as the water supplying the system was filtered, thereby minimizing the availability of natural plankton and particulate organic and inorganic matter, the natural food source of $C$. frondosa (Hamel \& Mercier 1998, Singh et al. 1998). The isotopic signatures of these food sources differed: values measured in waste material were $-22.4 \%$ for $\delta^{13} \mathrm{C}$ and $11.8 \%$ for $\delta^{15} \mathrm{~N}$, whereas values for plankton and particulate materials in Newfoundland were reported to be -23.5 and $3 \%$, respectively, by Ostrom \& Macko (1992) and Ostrom et al. (1997). The enrichment in the $\delta^{13} \mathrm{C}$ and $\delta^{15} \mathrm{~N}$ signatures of captive individuals in the present study is therefore consistent with processing and assimilation of the salmon waste materials. Another study conducted on a deposit feeder, 


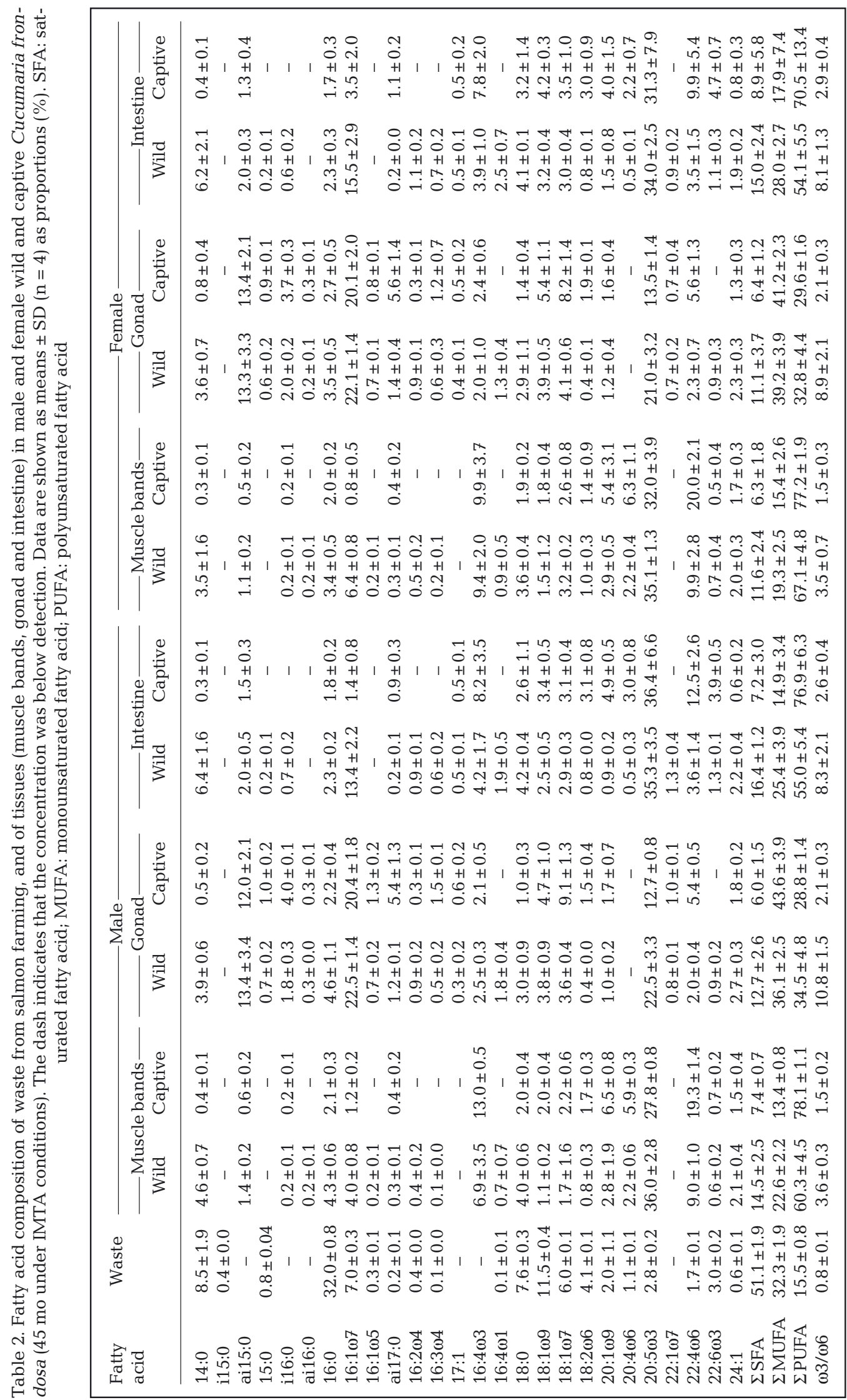


Australostichopus mollis, showed that isotope signatures of sea cucumbers at a farm site were more enriched relative to those of individuals from a natural site (Slater \& Carton 2007). Alternately, or additionally, some of the changes in $\delta^{13} \mathrm{C}$ and $\delta^{15} \mathrm{~N}$ signatures might be the result of long-term starvation, as supported by the weight loss recorded during the present study under IMTA conditions (discussed below).

Certain specific FAs have been successfully used as tracers of fish feed to determine its assimilation by aquatic animals (Gao et al. 2006, Redmond et al. 2010, Irisarri et al. 2015). Here, all tissues of the male and female individuals held in the IMTA system had greater levels of FA biomarkers of fish feed (18:1 $\omega 9$,

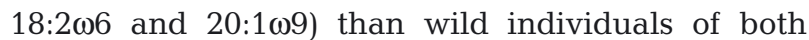
sexes, in line with a possible assimilation of residual feed by sea cucumbers. In addition, fish feed such as used in the present study now contains plant oils (Skog et al. 2003, Narváez et al. 2008), which are depleted in $\omega 3$ polyunsaturated FAs (PUFAs) and rich in $\omega 6$ PUFAs (Menoyo et al. 2007). Therefore, the lower $\omega 3 / \omega 6$ ratio recorded in all tissues of captive sea cucumbers compared to wild individuals further suggests that salmon feed was assimilated by sea cucumbers. Previous studies similarly showed the assimilation of fish feed by mussels cultured close to fish pens or supplemented with crushed fish pellets or fish effluents, based on the lower $\omega 3 / \omega 6$ ratio in their digestive gland and mantle tissue relative to those of mussels from a natural site (Gao et al. 2006, Redmond et al. 2010, Handå et al. 2012, Irisarri et al. 2015).

While the shift in biochemical composition supports an assimilation of particulate waste present in effluent water from salmon tanks, C. frondosa may not have been able to ingest enough of it (due to rapid sinking) or did not get nutrients of sufficient quality through this system based on its decreasing body size over the years. Insufficient or poor-quality food was described to induce auto-digestion of stored nutrient reserves in the different organs (including body wall and muscle bands), resulting in progressive weight loss (see below). Previous studies suggested that stable isotope analysis might serve as an index of nutritional stress (Gannes et al. 1997). Specifically, N isotope ratios appear to be particularly sensitive in that $\delta^{15} \mathrm{~N}$ of the whole body should increase with the duration of starvation (Hatch 2012). Therefore, the enrichment in the $\delta^{15} \mathrm{~N}$ signatures of captive individuals in the present study may be related to their long-term starvation. However, a number of studies have challenged this assumption (Gorokhova \& Hansson 1999, Hatch 2012), so whether starvation affected the stable iso- tope signatures of sea cucumbers in the present study remains to be clarified. What is clear is that the physical condition of sea cucumbers held for $4 \mathrm{yr}$ under IMTA differed from that of wild individuals; they were overall smaller, suggesting that the salmon waste did not provide adequate nourishment for their sustenance and growth. Muscle bands are one of the most important energy storage organs in C. frondosa, and their weight-based proportion is closely related to food supply and reproductive state (Hamel \& Mercier 1996a, Gianasi et al. 2017). The lower index of muscle bands in captive sea cucumbers further supports long-term malnutrition, whereby the energy stored in the muscle bands was used for other basal activities. In addition, spawning in captive sea cucumbers was only recorded in the first year of the 4 yr study, likely enabled by stored nutrients still present in the gonad. A third of captive individuals did not have a gonad at the end of the study, and in those that did, the gonad was not well developed relative to that of wild sea cucumbers collected concurrently. In addition to the availability of food, water temperature and depth, and light may play important roles in affecting the growth of animals and their gonad development (Hamel \& Mercier 1996b).

Previous studies have suggested that the biochemical composition of sea cucumbers was reflective of their diet (Yu et al. 2015, Wen et al. 2016, Gianasi et al. 2017), as also described in other taxa (Kanazawa et al. 1979). In the present study, differences in specific lipid classes between wild and captive sea cucumbers were observed. TAG in male and female tissues was greater in wild than captive individuals; this lipid class was described to play a role as energy storage in echinoderms and can be accumulated during periods of high food availability (Prowse et al. 2017). The variability of TAG likely reflects the different energy allocation strategies, i.e. how energy is distributed towards growth, survival and reproduction (Parzanini et al. 2018). For example, the proportion of TAG displayed increasing trends in the prespawning period, and declined in ovaries of $C$. frondosa post spawning (Verkaik et al. 2016, Gianasi et al. 2017). The reduction of TAG in captive individuals may suggest that they maximized their survival at the expense of preserving energetic lipid storage. Similarly, TAG decreased more slowly in fed than unfed larvae of the sea urchin Heliocidaris tuberculata (Prowse et al. 2017). However, the greater content of PL in captive $C$. frondosa may be related to the high content of PL in waste (main food source).

The present study also revealed that the FA composition of all the tissues of wild individuals differed 
from captive individuals of both sexes. The FA biomarker of diatoms, 16:4 $\omega 1$, was detected in all tissues of wild sea cucumbers but not in any tissue of captive individuals, and the content of 16:1 107 was greater in all tissues of wild than captive individuals. This supports the absence of diatoms as a food source in the IMTA system. However, the presence of bacterial FAs (i.e. ai15:0, 15:0, i16:0, ai16:0) (Kaneda 1991) in the tissues of both wild and captive individuals provides an indicator of bacterial contribution to their diet. In aquatic organisms, ARA, EPA and DHA are considered essential nutrients because they are required for optimal health (growth, reproduction, and immunity) and most of them are unable to synthesize them de novo (Parrish 2009). Here, the proportion of EPA in the gonad was lower in captive than wild individuals of both sexes, and DHA was not detected at all in the gonad of captive individuals. This may explain the poor gonad development and the lack of reproduction in captive sea cucumbers, which normally occurs every spring in the focal area (Mercier \& Hamel 2010).

The results of this study showed that suspensionfeeding sea cucumbers held downstream of salmon cultures exhibited shifts in both stable $\mathrm{C}$ and $\mathrm{N}$ isotopes, and in some specific FAs indicative of salmon feed. This suggests that $C$. frondosa can perform the role of an extractive species, assimilating and incorporating salmon-farming waste, and mitigating the accumulation of heavier solids, while providing an additional remunerative product. However, the poor physical condition established from organ indices and body size, associated with the change in biochemical composition of captive sea cucumbers, indicates that waste from fish farming may not completely meet their nutritional requirements for normal growth and reproduction, questioning the possibility of growing juveniles of $C$. frondosa to commercial size under such conditions. In other words, a natural diet including phytoplankton or lipid-rich suspended particulate matter may be crucial to maintain overall health in C. frondosa, which was not provided under the present salmon co-culture system. Further experimental trials will be required to obtain more precise information on the effects of salmon waste, what nutrients may be missing, whether supplements can offset any deficiencies and whether the flavor and texture of sea cucumbers from IMTA systems will be changed. Importantly, the present study was conducted in a land-based aquaculture facility using filtered seawater, whereas the most popular salmon farming method uses cages (pens) at sea. It is possible that such an open-ocean design could pro- vide enough natural seston for $C$. frondosa to remain healthy, although whether it would still ingest and assimilate salmon waste is uncertain. Additional work is needed to measure the assimilative capacity of suspension-feeding sea cucumbers inside various IMTA designs, including salmon floating pens and co-culture with other extractive species, such as bivalves.

Acknowledgements. We received funding from the China Scholarship Council (no. 201506330060 to J.S.), the Canadian Centre for Fisheries and Innovation (no. 209293 to A.M.) and the Department of Fisheries and Aquaculture, Government of Newfoundland and Labrador (no. 209317 to A.M.). Support for some of the analytical work was provided by the Ocean Frontier Institute, through an award from the Canada First Research Excellence Fund (to A.M.). Many thanks to E. Montgomery for sample collection, J. Wells and A. Pye for technical support, as well as C. Pearce, M. Slater, C. Parrish and 2 anonymous reviewers for constructive comments. The IMTA system at College of the North Atlantic was supported through grants from the Natural Sciences and Engineering Research Council (Canada) and the Department of Tourism, Culture, Industry and Innovation (Newfoundland).

\section{LITERATURE CITED}

Abreu MH, Pereira R, Yarish C, Buschmann AH, SousaPinto I (2011) IMTA with Gracilaria vermiculophylla: productivity and nutrient removal performance of the seaweed in a land-based pilot scale system. Aquaculture 312:77-87

Ahlgren MO (1998) Consumption and assimilation of salmon net pen fouling debris by the red sea cucumber Parastichopus californicus: implications for polyculture. J World Aquacult Soc 29:133-139

KChatvijitkul S, Boyd CE, Davis DA, McNevin AA (2017) Pollution potential indicators for feed-based fish and shrimp culture. Aquaculture 477:43-49

Chopin T, Cooper JA, Reid G, Cross S, Moore C (2012) Open water integrated multi trophic aquaculture: environmental biomitigation and economic diversification of fed aquaculture by extractive aquaculture. Rev Aquacult $4: 209-220$

DFO (Fisheries and Oceans Canada) (2017) Farmed salmon. https://www.dfo-mpo.gc.ca/aquaculture/sector-secteur/ species-especes/salmon-saumon-eng.htm (accessed on 13 Feb 2020)

Gannes LZ, O'Brien DM, Del Rio CM (1997) Stable isotopes in animal ecology: assumptions, caveats, and a call for more laboratory experiments. Ecology 78:1271-1276

Gao QF, Shin PK, Lin GH, Chen SP, Cheung SG (2006) Stable isotope and fatty acid evidence for uptake of organic waste by green-lipped mussels Perna viridis in a polyculture fish farm system. Mar Ecol Prog Ser 317:273-283

Gianasi BL, Hamel JF, Mercier A (2016) Experimental test of optimal holding conditions for live transport of temperate sea cucumbers. Fish Res 174:298-308

Gianasi BL, Parrish CC, Hamel JF, Mercier A (2017) Influence of diet on growth, reproduction and lipid and fatty acid composition in the sea cucumber Cucumaria frondosa. Aquacult Res 48:3413-3432 
Gorokhova E, Hansson S (1999) An experimental study on variations in stable carbon and nitrogen isotope fractionation during growth of Mysis mixta and Neomysis integer. Can J Fish Aquat Sci 56:2203-2210

Hamel JF, Mercier A (1996a) Studies on the reproductive biology of the Atlantic sea cucumber Cucumaria frondosa. SPC Beche-de-mer Inf Bull 8:22-33

Hamel JF, Mercier A (1996b) Early development, settlement, growth, and spatial distribution of the sea cucumber Cucumaria frondosa (Echinodermata: Holothuroidea). Can J Fish Aquat Sci 53:253-271

Hamel JF, Mercier A (1998) Diet and feeding behaviour of the sea cucumber Cucumaria frondosa in the St. Lawrence estuary, eastern Canada. Can J Zool 76:1194-1198

Hamel JF, Mercier A (2008) Precautionary management of Cucumaria frondosa in Newfoundland and Labrador, Canada. In: Toral-Granda MV, Lovatelli A, Vasconcellos $M$ (eds) Sea cucumbers: a global review of fisheries and trade. Fish Aquacult Tech Pap 516. FAO, Rome, p 293-306

Handå A, Ranheim A, Olsen AJ, Altin D, Reitan KI, Olsen Y, Reinertsen H (2012) Incorporation of salmon fish feed and feces components in mussels (Mytilus edulis): implications for integrated multi-trophic aquaculture in cooltemperate North Atlantic waters. Aquaculture 370-371: 40-53

* Hannah L, Pearce C, Cross S (2013) Growth and survival of California sea cucumbers (Parastichopus californicus) cultivated with sablefish (Anoplopoma fimbria) at an integrated multi-trophic aquaculture site. Aquaculture 406-407:34-42

Hatch KA (2012) The use and application of stable isotope analysis to the study of starvation, fasting, and nutritional stress in animals. In: McCue MD (ed) Comparative physiology of fasting, starvation, and food limitation. Springer, Berlin, p 337-364

Irisarri J, Fernández-Reiriz MJ, Labarta U, Cranford PJ, Robinson SM (2015) Availability and utilization of waste fish feed by mussels Mytilus edulis in a commercial integrated multi-trophic aquaculture (IMTA) system: a multiindicator assessment approach. Ecol Indic 48:673-686

Jobling M, Arnesen AM, Befey T, Carter C and others (2010) The salmonids (family: Salmonidae). In: LeFrancoid N, Jobling M, Carter C, Biler P (eds) Finfish aquaculture diversification. CABI, Wallingford, p 234-288

Jordan AJ (1972) On the ecology and behavior of Cucumaria frondosa (Echinodermata: Holothurioidea) at Lamoine Beach, Maine. PhD dissertation, University of Maine, Orono, ME

Kanazawa A, Teshima S, Ono K (1979) Relationship between essential fatty acid requirements of aquatic animals and the capacity for bioconversion of linolenic acid to highly unsaturated fatty acids. Comp Biochem Physiol Part B Comp Biochem 63:295-298

Kaneda T (1991) Iso-and anteiso-fatty acids in bacteria: biosynthesis, function, and taxonomic significance. Microbiol Rev 55:288-302

Kang KH, Kwon JY, Kim YM (2003) A beneficial coculture: charm abalone Haliotis discus hannai and sea cucumber Stichopus japonicus. Aquaculture 216:87-93

Kang YH, Shin JA, Kim MS, Chung IK (2008) A preliminary study of the bioremediation potential of Codium fragile applied to seaweed integrated multi-trophic aquaculture (IMTA) during the summer. J Appl Phycol 20:183-190

*MacDonald BA, Robinson SM, Barrington KA (2011) Feed- ing activity of mussels (Mytilus edulis) held in the field at an integrated multi-trophic aquaculture (IMTA) site (Salmo salar) and exposed to fish food in the laboratory. Aquaculture 314:244-251

*Maxwell KH, Gardner JP, Heath PL (2009) The effect of diet on the energy budget of the brown sea cucumber, Stichopus mollis (Hutton). J World Aquacult Soc 40:157-170

Mayor DJ, Solan M (2011) Complex interactions mediate the effects of fish farming on benthic chemistry within a region of Scotland. Environ Res 111:635-642

Menoyo D, Lopez-Bote CJ, Diez A, Obach A, Bautista JM (2007) Impact of $n-3$ fatty acid chain length and $n-3 / n$ - 6 ratio in Atlantic salmon (Salmo salar) diets. Aquaculture 267:248-259

*Mercier A, Hamel JF (2010) Synchronized breeding events in sympatric marine invertebrates: role of behavior and fine temporal windows in maintaining reproductive isolation. Behav Ecol Sociobiol 64:1749-1765

* Montgomery E, Ferguson-Roberts J, Gianasi B, Hamel JF, Kremenetskaia A, Mercier A (2018) Functional significance and characterization of sexual dimorphism in holothuroids. Invertebr Reprod Dev 62:191-201

* Narváez M, Freites L, Guevara M, Mendoza J, Guderley H, Lodeiros C, Salazar G (2008) Food availability and reproduction affects lipid and fatty acid composition of the brown mussel, Perna perna, raised in suspension culture. Comp Biochem Physiol B Biochem Mol Biol 149:293-302

Navarrete-Mier F, Sanz-Lázaro C, Marín A (2010) Does bivalve mollusc polyculture reduce marine fin fish farming environmental impact? Aquaculture 306:101-107

Nelson E, MacDonald B, Robinson S (2012) The absorption efficiency of the suspension-feeding sea cucumber, Cucumaria frondosa, and its potential as an extractive integrated multi-trophic aquaculture (IMTA) species. Aquaculture 370-371:19-25

Neori A, Chopin T, Troell M, Buschmann AH and others (2004) Integrated aquaculture: rationale, evolution and state of the art emphasizing seaweed biofiltration in modern mariculture. Aquaculture 231:361-391

* Orr LC, Curtis DL, Cross SF, Gurney-Smith H, Shanks A, Pearce CM (2014) Ingestion rate, absorption efficiency, oxygen consumption, and fecal production in green sea urchins (Strongylocentrotus droebachiensis) fed waste from sablefish (Anoplopoma fimbria) culture. Aquaculture 422-423:184-192

Ostrom NE, Macko SA (1992) Sources, cycling, and distribution of water column particulate and sedimentary organic matter in northern Newfoundland fjords and bays: a stable isotope study. In: Whelan JK, Farrington JW (eds) Organic matter: productivity, accumulation, and preservation in recent and ancient sediments. Columbia University Press, New York, NY, p 55-81

Ostrom NE, Macko SA, Deibel D, Thompson RJ (1997) Seasonal variation in the stable carbon and nitrogen isotope biogeochemistry of a coastal cold ocean environment. Geochim Cosmochim Acta 61:2929-2942

* Paltzat D, Pearce C, Barnes P, McKinley R (2008) Growth and production of California sea cucumbers (Parastichopus californicus Stimpson) co-cultured with suspended Pacific oysters (Crassostrea gigas Thunberg). Aquaculture 275:124-137

Parrish CC (1999) Determination of total lipid, lipid classes, and fatty acids in aquatic samples. In: Arts MT, Wainman BC (eds) Lipids in freshwater ecosystems. Springer, New York, NY, p 4-20 
Parrish CC (2009) Essential fatty acids in aquatic food webs. In: Kainz M, Brett MT, Arts MT (eds) Lipids in aquatic ecosystems. Springer, New York, NY, p 309-326

Parzanini C, Parrish CC, Hamel JF, Mercier A (2018) Functional diversity and nutritional content in a deep-sea faunal assemblage through total lipid, lipid class, and fatty acid analyses. PLOS ONE 13:e0207395

Peterson BJ, Fry B (1987) Stable isotopes in ecosystem studies. Annu Rev Ecol Syst 18:293-320

Pillay TVR (2008) Aquaculture and the environment. Blackwell Publishing, Oxford

Post DM (2002) Using stable isotopes to estimate trophic position: models, methods, and assumptions. Ecology 83: 703-718

Prowse TAA, Sewell MA, Byrne M (2017) Three-stage lipid dynamics during development of planktotrophic echinoderm larvae. Mar Ecol Prog Ser 583:149-161

Redmond KJ, Magnesen T, Hansen PK, Strand Ø, Meier S (2010) Stable isotopes and fatty acids as tracers of the assimilation of salmon fish feed in blue mussels (Mytilus edulis). Aquaculture 298:202-210

Reid G, Liutkus M, Bennett A, Robinson S, MacDonald B, Page F (2010) Absorption efficiency of blue mussels (Mytilus edulis and M. trossulus) feeding on Atlantic salmon (Salmo salar) feed and fecal particulates: implications for integrated multi-trophic aquaculture. Aquaculture 299:165-169

Ren Y, Dong S, Wang X, Gao Q, Jiang S (2014) Beneficial co culture of jellyfish Rhopilema esculenta (Kishinouye) and sea cucumber Apostichopus japonicus (Selenka): implications for pelagic benthic coupling. Aquacult Res 45:177-187

Ridler N, Wowchuk M, Robinson B, Barrington K and others (2007) Integrated multi-trophic aquaculture (IMTA): a potential strategic choice for farmers. Aquacult Econ Manag 11:99-110

Shpigel M, Neori A, Popper DM, Gordin H (1993) A proposed model for 'environmentally clean' land-based culture of fish, bivalves and seaweeds. Aquaculture 117:115-128

Singh R, MacDonald BA, Lawton P, Thomas ML (1998) Feeding response of the dendrochirote sea cucumber Cucumaria frondosa (Echinodermata: Holothuroidea) to changing food concentrations in the laboratory. Can J Zool 76:1842-1849

Skog TE, Hylland K, Torstensen BE, Berntssen MH (2003) Salmon farming affects the fatty acid composition and taste of wild saithe Pollachius virens L. Aquacult Res 34: 999-1007

Editorial responsibility: Adam Hughes, Oban, UK
Slater MJ, Carton AG (2007) Survivorship and growth of the sea cucumber Australostichopus (Stichopus) mollis (Hutton 1872) in polyculture trials with green-lipped mussel farms. Aquaculture 272:389-398

So JJ, Hamel JF, Mercier A (2010) Habitat utilisation, growth and predation of Cucumaria frondosa: implications for an emerging sea cucumber fishery. Fish Manag Ecol 17:473-484

Sterling AM, Cross SF, Pearce CM (2016) Co-culturing green sea urchins (Strongylocentrotus droebachiensis) with mussels (Mytilus spp.) to control biofouling at an integrated multi-trophic aquaculture site. Aquaculture 464:253-261

* Troell M, Joyce A, Chopin T, Neori A, Buschmann AH, Fang JG (2009) Ecological engineering in aquaculturepotential for integrated multi-trophic aquaculture (IMTA) in marine offshore systems. Aquaculture 297:1-9

Verkaik K, Hamel JF, Mercier A (2016) Carry-over effects of ocean acidification in a cold-water lecithotrophic holothuroid. Mar Ecol Prog Ser 557:189-206

*Wang X, Olsen LM, Reitan KI, Olsen Y (2012) Discharge of nutrient wastes from salmon farms: environmental effects, and potential for integrated multi-trophic aquaculture. Aquacult Environ Interact 2:267-283

*Wen B, Gao QF, Dong SL, Hou YR, Yu HB, Li WD (2016) Effects of different feed ingredients on growth, fatty acid profiles, lipid peroxidation and aminotransferases activities of sea cucumber Apostichopus japonicus (Selenka). Aquaculture 454:176-183

Fokoyama H (2013) Growth and food source of the sea cucumber Apostichopus japonicus cultured below fish cages - potential for integrated multi-trophic aquaculture. Aquaculture 372-375:28-38

Yokoyama H (2015) Suspended culture of the sea cucumber Apostichopus japonicus below a Pacific oyster raftpotential for integrated multi trophic aquaculture. Aquacult Res 46:825-832

*Yu HB, Gao QF, Dong SL, Wen B (2015) Changes in fatty acid profiles of sea cucumber Apostichopus japonicus (Selenka) induced by terrestrial plants in diets. Aquaculture 442:119-124

Kamora LN, Yuan X, Carton AG, Slater MJ (2018) Role of deposit feeding sea cucumbers in integrated multitrophic aquaculture: progress, problems, potential and future challenges. Rev Aquacult 10:57-74

Khou Y, Yang H, Liu S, Yuan X and others (2006) Feeding and growth on bivalve biodeposits by the deposit feeder Stichopus japonicus Selenka (Echinodermata: Holothuroidea) co-cultured in lantern nets. Aquaculture 256: $510-520$

Submitted: November 29, 2019; Accepted: March 3, 2020 Proofs received from author(s): April 3, 2020 